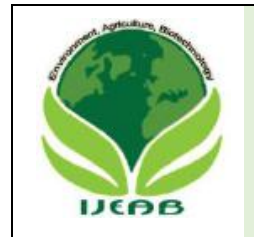

\title{
The Impact of COVID-19 on the Atmosphere, Hydrosphere and Biosphere: A global scenario
}

Peer-Reviewed Journal

\author{
Atreyi Ghosh*, Arghya Nath, Parna Dey Banik, Ratnadeep Chowdhury, Debanita Mandal
}

Department of Microbiology and Biotechnology, Sister Nivedita University, India

*Corresponding Author

Received: 27 Mar 2021; Received in revised form: 02 May 2021; Accepted: 19 May 2021; Available online: 07 Jun 2021

(C)2021 The Author(s). Published by Infogain Publication. This is an open access article under the CC BY license

(https://creativecommons.org/licenses/by/4.0/).

\begin{abstract}
The human life had come to a stagnant condition as many countries had to shut down all sorts of internal and external communication from due to the spread of extremely contagious disease of COVID19. Social distancing of different levels has been a common scenario in all the countries which had made the whole world to a standstill. The industries, transportation, and other activities suddenly came to a pause for the developed and developing countries all across the globe. The atmosphere, hydrosphere and the biosphere have been polluted for last few decades due to various anthropogenic activities all around the world. The air and water pollution got reduced due to less carbon emission and the reduced decarbonization rate first time observed in the modern Anthropocene. The water quality of rivers, lakes, fresh water and sea water has been reported to be improved during this pandemic situation. The drastic reduction in human activity resulted the reduction of atmospheric $\mathrm{NO}_{2}, \mathrm{CO}_{2}$ and particulate matters in air which led to clean air and pollution free water in many countries and also the wildlife took the opportunity to regain their natural space. Although the situation was in favor of environment, the water in-fluent and the waste water has been reported to have SARS-CoV-2 RNA and also,it's been a great deal of concern for the increased use of medical and plastic waste and their inappropriate disposal which is followed by the health hazards. This review article provides evidence-based analysis of good and bad effect on the global environment during the worldwide lockdown situation. A summary of the published articles of the environmental effects of COVID-19 pandemic have been discussed and the significant facts have been discussed focusing on several relevant aspects like, air quality, water quality, waste management, wildlife and conservation. An attempt has been made to visualize the world scenario.
\end{abstract}

Keywords-COVID-19, Atmosphere, Hydrosphere, Biosphere, Anthropocene.

\section{INTRODUCTION}

COVID-19 is the novel coronavirus which causes unusual pneumonia had first occurred in Wuhan, China on December, 2019. The highly contagious nature of the novel coronavirus had been the threat worldwide since then. The disease crossed Chinese borders and spread almost in all countries across the globe [1][2][3].

The spread of the virus is still continuing in all the affected countries. Till 28th of August 2020, COVID19 positive cases was more than $24,373,497$ and worldwide death toll had crossed more than 830,518 . Transmission of the novel corona virus had spread to remote countries like Italy, Iran,
South Korea, and many other countries. The speedy spread of the disease had made the epidemiologists sure that he virus could not be confined to the borders of China. [4][5][6].

The symptoms of the novel corona virus include fever, dry cough, fatigue and respiratory choke and also loss of smell and nasal congestion. Severity of the symptoms have been reported to be dependent on the patient's innate immunity. Also, it has been found that the elderly people and patients who are already suffering from other diseases or disorders like cancer, diabetes, hypertension, asthma, cardiac 
diseases because their innate immunity is weaker than a normal person [7][8][9][10].

COVID-19 pandemic has made a strong footprint on almost each and every aspect of Anthropocene already. To restrict the spread of the infection, every country had to impose many quarantine rules and had to shut down local transports, small and large business, offices, educational institutions etc. above all the national and international aviation had come to complete halt during the worldwide lockdown period in early 2020 .

Although the COVID-19 pandemic had caused a disaster worldwide in terms of death toll, economic loss and spike in deuteriation of mental health, the global environment has been observed to have improved significantly. The complete shutdown of the transportation had led a drastic increase in decarbonization which in turn have been the reason of the significant improvement in Air and water quality in many countries. A significant reduction in air and water pollution has been reported by many researchers. The concentration of $\mathrm{NO}_{2}, \mathrm{CO}$ and particulate matterhas been reported to be reduced in many countries around the world. The impact of COVID-19 on the betterment of overall quality of water bodies have also been reported. Also, the lockdown condition has restricted the human invasion in the natural habitats of wild animals and as a result the wildlife got more space to be inhabited and breed freely without the fear of human interference.

In this current review, the direct and indirect impact of COVID-19 in the global aspect has been discussed in a detailed manner. The effect on atmosphere, water, wastewater and wildlife has been analyzed including the current challenge of medical and other solid waste disposal.

\section{COVID-19 and Air pollution:}

The lockdown situation had a positive impact on air quality specially in metro cities all around the globe. COVID-19 lockdown has led to an overall drop in carbon emissions in several cities.

Because of the lockdown situation, $\mathrm{NO}_{2}$ was found to be reduced by $22.8 \mu \mathrm{g} / \mathrm{m}^{3}$ and $12.9 \mu \mathrm{g} / \mathrm{min}$ Wuhan and China, respectively. Particulate matter (PM 2.5) was found to be reduced by $1.4 \mu \mathrm{g} / \mathrm{m}^{3}$ in Wuhan and also reduced by 18.9 $\mu \mathrm{g} / \mathrm{m}^{3}$ in 367 cities in China. Data collected from the Copernicus Sentinel-5P satellite has revealed a decrease in $\mathrm{NO}_{2}$ concentrations in Rome, Madrid, and Paris which are the first European cities where strict quarantine measures have been implemented [11].
In a recent study carried out by [12] the environmental impact of COVID-19 outbreak has been studied using the spatio-temporal satellite-based products to measure the amount of $\mathrm{NO}_{2}, \mathrm{CO}$, and Aerosol optical density (AOD). In that study it has been mentioned that there has been a significant decrease in all these three parameters which are responsible for air pollution. In another study it has been stated that there has been a significant reduction in particulate matter pollution among European cities like Greece, Portugal, Finland, Norway, Poland, Sweden, and Spain during the lockdown period. The decrease in the amount of $\mathrm{NO} 2$ and AOD were attributed to the reduction of fossil fuel usage in those areas during that period.

In a study done by some scientists [13] in the changes in the air quality parameters have been studied extensively in the city of Ghaziabad. The city of Ghaziabad is situated in Western Uttar Pradesh, India. The environmental condition of the city is almost similar to that of Delhi. Fig. 1 shows the amount of AOD in the atmosphere of India during the period of March 31st and April $5^{\text {th }}$ for six subsequent years (2016-2020) which has been mentioned in the study. In the figures the yellow pixel and bluish pixels indicates a little or very low concentration of aerosol respectively and the dark brown pixels indicates very high concentration. From the figure it is very obvious that the AOD concentration has decreased drastically in 2020 which is a clear indication the positive impact of COVID 19 situation on air quality in that particular region. Similar findings have also been reported by European Space agency where the atmospheric $\mathrm{NO}_{2}$ had reached to a very low level of around $40-50 \%$ across major cities in India. The satellite images also revealed the drastic reduction in the particulate matter (PM). The views taken by satellite clearly shows the reduction of concentration of PM2.5 and PM10 in the span of one month in the Northern and eastern states of India including the capital city of New Delhi. Air Quality Index is an overall scheme proposed by Central Pollution Control board (CPCB) [14] which includes the weighted values of seven air pollutants (PM2.5, PM10, $\mathrm{CO}, \mathrm{NH}_{3}$, $\mathrm{NO}_{2}, \mathrm{SO}_{2}$ and Ozone) in to a single number or set of numbers. The study shows that the air quality index has been improved significantly in India after the COVID 19 outbreak.

According to the study by [12] countries which has average temperatures between $4{ }^{\circ} \mathrm{C} \pm 2{ }^{\circ} \mathrm{C}$ to $\sim 19{ }^{\circ} \mathrm{C} \pm 2$ ${ }^{\circ} \mathrm{C}$ and atmospheric humidity (AH): 4 to $9 \mathrm{~g} \mathrm{~m}^{-3}$ are at a greater risk of the spread of novel corona virus. 


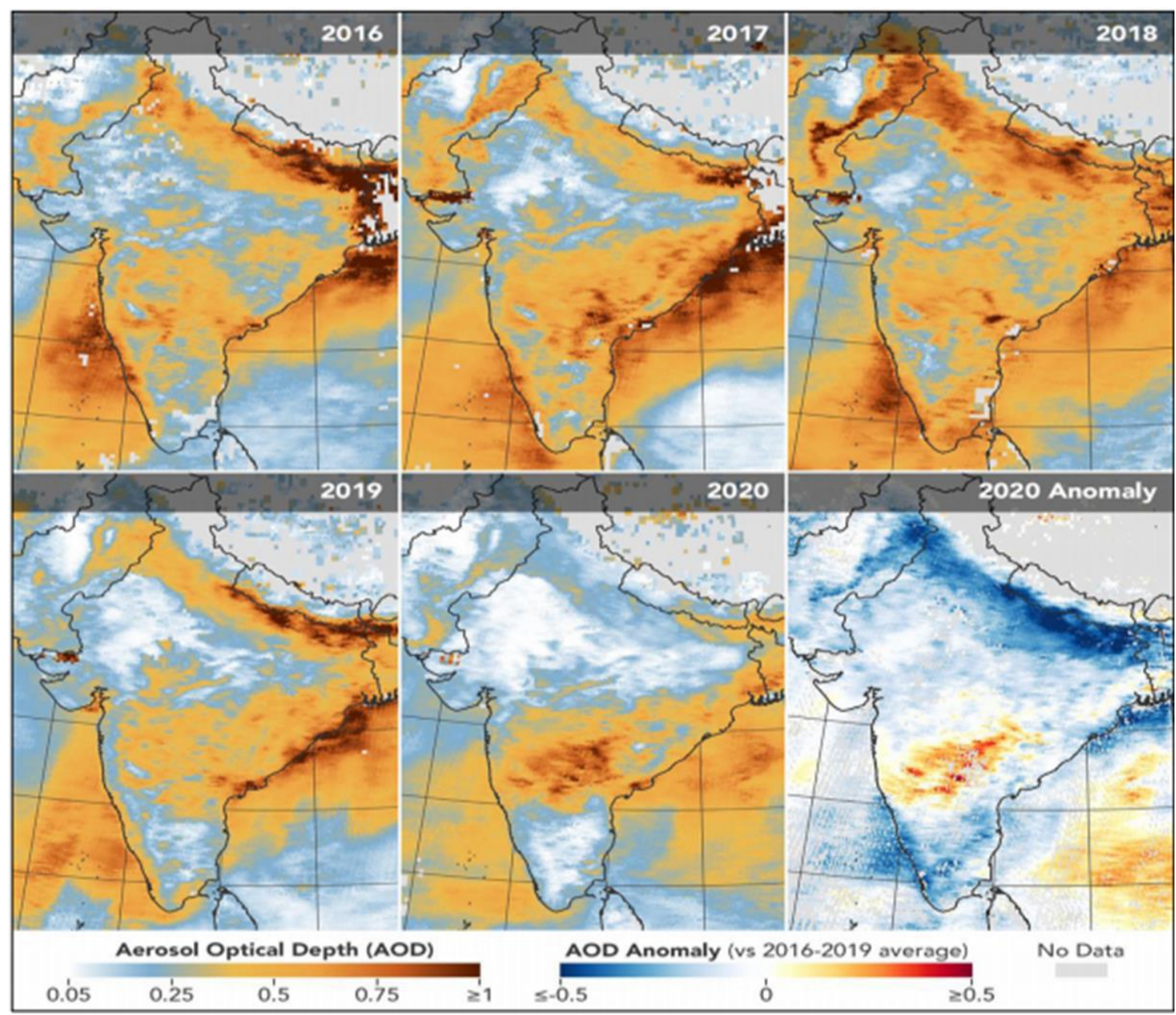

Fig 1: AOD concentration in India from the period March 31 to April 5 in 2016-2020

\section{COVID-19 AND WILDLIFE}

COVID-19 crisis has stopped people's activities in a great extent. Restrictions on business, traveling, public transport etc. have created a direct impact on the activities of foraging wildlife, illegal poaching, conversion of habitat for agriculture, and other activities of resource extraction to support livelihoods have been the reason for creation of constant threat towards biodiversity [15][16][17][18][19]. A data published by Wildlife Institute of India entitled as "Lockdown Wildlife Tracker" shows uninterrupted movement of wildlife in people reigned areas. This data has encouraged the volunteers for documentation of wildlife actions in those areas and the collected data can be available to the research community for investigation [20]. There have been many reports of movements of wild animals in the human-dominated space. Wild boars were observed in Italy, wild coyotes and dears have been spotted in the USA, peacocks in Bangor, goats in Wales and rare insects in the UK. wild boar in Barcelona and Bergamo, Italy. Also, it has been observed that the Moles have been crawling the footpaths. Locals of UK have noticed the highest blooming of wild flowers [21][22]. Also, the wildlife killing through road-accidents have been reported to be reduced drastically. Number of trucks and cars have been very less in number during the lockdown situation which has caused the lower toll for road kills [20]. Those instances of expanding natural habitats of wildlife have proved how the environment can rejuvenate itself within a short period of time and it also the extent of distortion of environment has occurred due to human interference. The observation indicates the necessity of strict administrative actions to be adapted in post-COVID19 period to implement prohibition in human interference to nurture the natural environment [20].

During the lockdown period, increase in the activity of alien species has been reported by a study by [6]. Eastern cottontail (Sylvilagus floridanus) has been funding to intrude in the protected areas. In the same study, there has been reports of probable invasion by alien species from surrounding sites because of the absence of barrier of roads and presence of humans there. Also, they have reported that the lack of invasion of problem-causing 
mammals for example, wild boars Sus scrofa increasing the threat of endangered animals and plants in those areas. The reduction of conservation of native species have been accompanied with the reduction of alien species eradication activities. In a nutshell, the ongoing conservation actions have been facing a high risk of failure because of the lockdown [6].

During the pandemic situation, many researchers have encouraged governments to prohibit the wildlife trade to eradicate the chance of spreading infectious diseases like COVID-19. Governments of many countries are implementing rigid efforts to forbid wildlife trade for example, China has forced restrictions on wildlife trade specifically wolfs, civets, pangolin and bats [23].

Although in the present scenario there is a probability of the poorer countries of the southern hemisphere to be in fear because of an increased threat to wildlife due to the decreased economic capacity in pandemic situation. Those countries are likely to have less money and officials to provide necessary conservation of the endangered and vulnerable species and their habitats [21].

\section{COVID-19 ON WATER}

The betterment of the environmental quality of atmosphere and hydrosphere have been observed during the worldwide lockdown situation. There has been reports of cleaning of surface water like, lakes, rivers etc. from many countries around the world. Apart from the decrease in the level of greenhouse gases in the atmosphere, the solid particulate matter (SPM) of surface water like, lakes and rivers has been reported to be decreased in a significant level in India, Italy and UK [23][24]. The drastic decrease in the water way travelling through the water bodies has caused the water to settle and the SPM to decrease in a significant level. This resulted the return of the aquatic organisms to return to previously traveled waters at the coastal areas and more birds in the

surrounding area with fewer human interventions. At the end of March 2020, the boats and ships were restricted in the sea coast in Britain which transformed the dark waters of the coastline into much clearer blue hue [14]. Pictures of a cleaner River Ganga could be taken from both the regions of Kanpur and Varanasi at the state of Uttar
Pradesh, India. The clean water. Also, there has been reports of the visibility of fishes at the banks of the river at Varanasi, which could be attributed to the closure of industries releasing toxic effluents into the water and also overpopulated ghats at the river banks [24].

In a very recent article [13] they have reported that the overall water quality of main rivers of India namely Ganga, Cauvery, Sutlej and Yamuna have been improved during the nationwide lockdown period. The causes of the improvement are lack of industrial effluents entering the rivers, reduction of demand of irrigation water, increased level of rainfall and also reduction of religious and cultural activities on the banks of the rivers during the pandemic situation. The dissolved oxygen (DO) levels of river Ganga has become above $8 \mathrm{ppm}$ and biological oxygen demand (BOD) levels down below 3 ppm at some parts [26].

Scientists have claimed that water quality has remarkably improved up to drinking standards at some region of the banks of river Ganga. River Yamuna also in most parts of Delhi has been observed to be clearer and blue after decades. The toxic foam carrying detergents and chemicals effluents of industries and sewage have disappeared [13]. Also, in the southern part of India, the water quality of Cauvery and tributaries like, Hemavati, Kabini, Shimsha and Lakshamanathirtha was also improved.

A group of scientists [25] studied the effect of lockdown situation on the lake of Vembanad, the longest freshwater lake in India situated in southern India. They have suggested the lake Vembanad which is surrounded by densely populated areas ( 810 inhabitants $\left./ \mathrm{km}^{2}\right)$ have shown to reduce the SPM concentration by $15.9 \%$ compared to the pre lockdown period. Fig. 2 shows the results of the mentioned study through remote sensing images of the SPM. The data of SPM analyzed on April 2020 was the lowest for 11 out of 20 zones of the Vembanad lake. It was concluded from the study that the sustainability of the improvement depends on the consideration of the reduction of human intervention such as tourism, socioeconomic and religious activities [25]. 

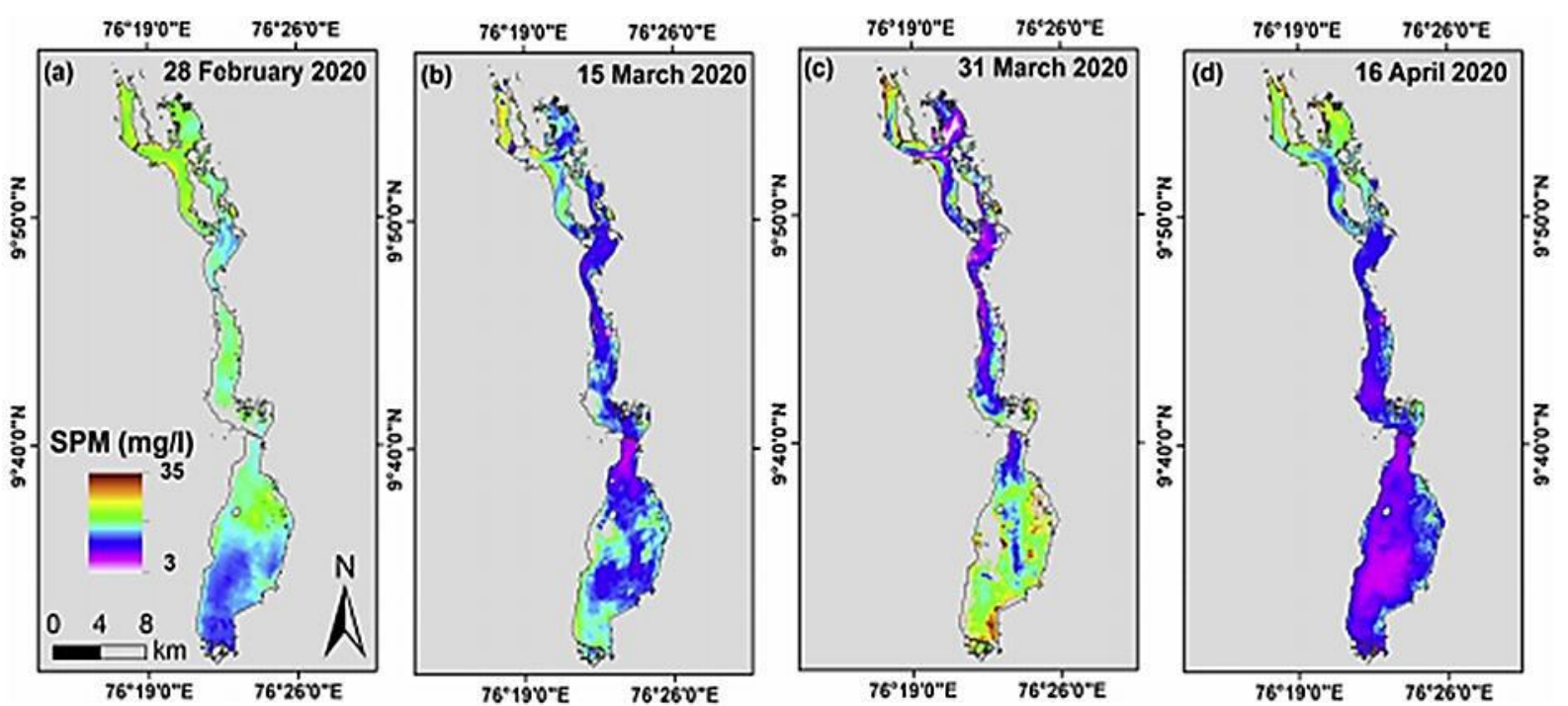

Fig. 2. Suspended particulate matter (SPM) concentrations estimated for the Vembanad lake on 28th February, 15th and 31 st March, and 16th April 2020 (values in $\mathrm{mg} / \mathrm{l}$; violet is low and dark red is the highest concentration).

\section{COVID-19 on waste-water}

There have been worldwide reports of presence of novel corona virus in the waste-water systems [27][28][29]. The occurrence of the virus has been reported in stool samples collected from symptomatic and asymptomatic patients as well as in municipal waste-waters across the globe including western and oriental countries [30][31][32][33]. RNA fragments of SARS-CoV-2 have been reported to be present in the feces of infected individuals. The findings indicates that the virions are getting liberated from the gastrointestinal tracts of the infected patient. Also, it has been reported that fecal samples remain positive for the novel corona virus for a significantly longer period of time in comparison with the samples collected from upper respiratory tract [34]. The fate of SARS-CoV-2 in the water supply and areas of potential human exposure has been depicted in figure 3 which has been adopted from the study carried out by [34][35].

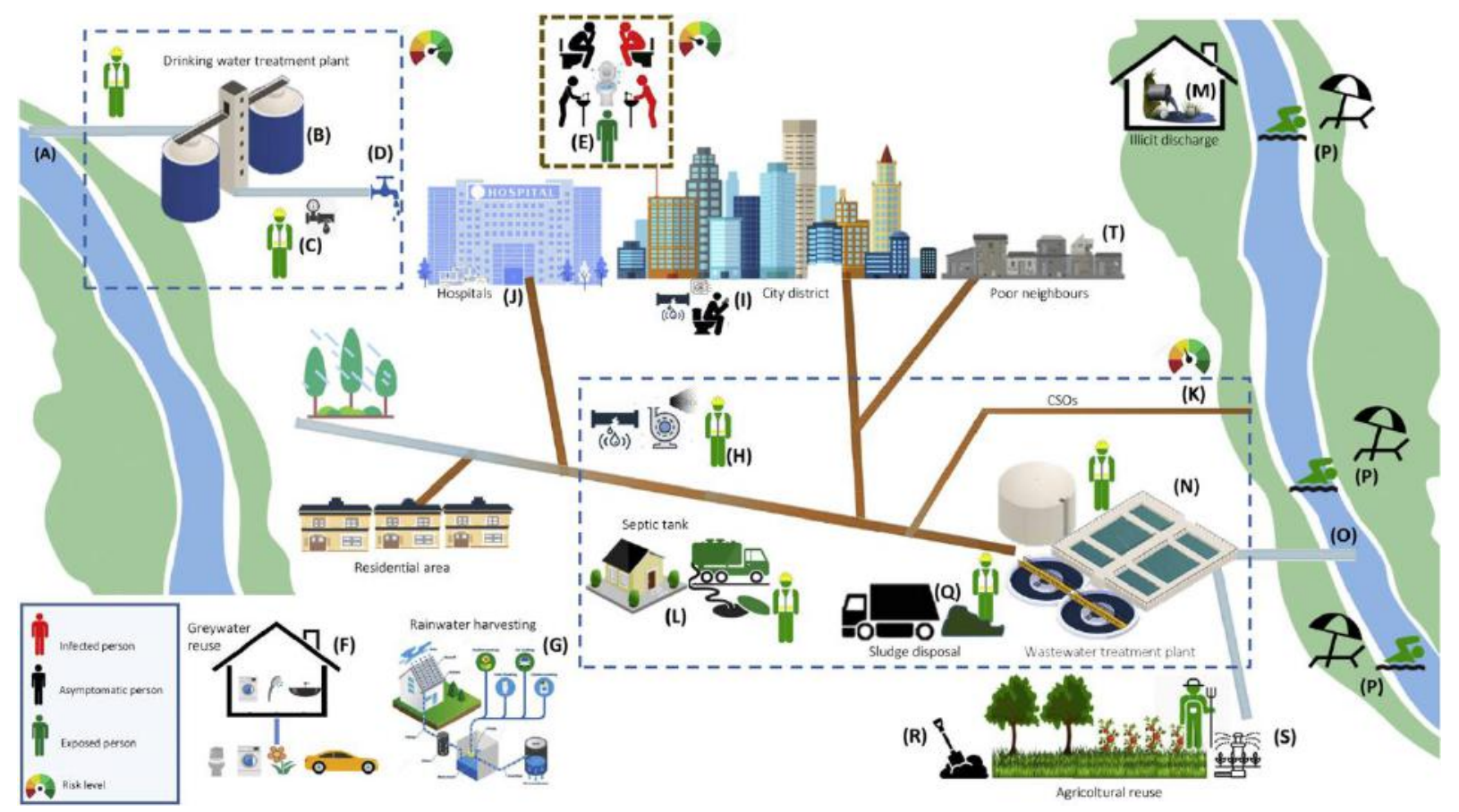

Fig.3: Potential fate of SARS-CoV-2 in the water service and locations of potential human exposure (Wigginton et al. 2015 and Langone 2020) 
In a recent study, it has been found that SARS-CoV-2 RNA have been found to be present in the urine sample of an infected individual. Also, two adult urine samples have been detected to be positive for 3 days and up to 4 days for one child urine sample [36]. These results indicates that the waste-waters may contain both RNA fragments and viable virus.

SARS-CoV-2 have been found in waste-water samples in several cities worldwide including Milan, Rome, Massachusetts, Paris, Brisbane and Murcia. The detection of the virus has been done using different methods. Although the presence of high number of copies of RNA, the longevity of SARS-CoV-2 in raw wastewater below significant level [37]. Effluent coming out of the plants treating waste-water by peracetic acid or high intensity UV lamps, were mostly found to be negative for SARS-CoV-2. This indicates the effectiveness of wastewater treatments [37].

There are some reports of the inactivation of SARS-CoV2 in ethanol $(70 \%)$ and chlorine-based disinfectants with active chlorine of $0.1 \%$ for a contact time of $5 \mathrm{~min}$ in room temperature. Ultraviolet light has also been reported to be effective against Coronaviruses. Antagonist microorganisms present in water can also reported to increase the extent of thevirus's inactivation [34].

The most commonly used methods for the detecting SARS-CoV-2 is the reverse transcription-polymerase chain reaction (RT-PCR) and the reverse transcriptase quantitative polymerase chain reaction (RT-qPCR) in water and waste-water [38][39][40] have reported the effectiveness of RT-PCR to detect SARS-CoV-2 in the different specimens like feces, urine, sputum, blood, and nasal discharge of infected patients. Also, viral RNA detection using RT-PCR has been used commonly as the standard method for detecting RNA of SARS-CoV-2 from clinical specimens.

\section{Solid waste and COVID-19:}

During the pandemic situation, the sudden increment of the use of single use plastics and the medical wastes has been a serious concern of the cities and urban areas all across the globe. Cities which are facing high COVID-19 infection rates are struggling hard to manage the sudden increase in medical waste production [41][42][10]. The King Abdullah University Hospital in Jordan produced tenfold higher medical waste $(\sim 650 \mathrm{~kg}$ per day, when considering an occupation of 95 COVID-19 patients) than the average generation rate during the regular operational day of the hospital [10]. Different types of medical and hazardous substances have been generated during the COVID 19 pandemic, including infected masks, gloves, used bottles of hand and surface sanitizers along with the existing wastes of the same nature. Therefore, it has become a prime necessity to manage the biomedical and healthcare waste and also the appropriate identification, collection, separation, storage, transportation, treatment and disposal of those waste and also other significant aspects like training related to personal protection [42]. A drastic increase in medical waste was also reported in Catalonia, Spain, and in China, with an increment of $350 \%$ and $370 \%$, respectively. The sudden increase in medical waste is far beyond the capacity of any country or municipality, to manage or treat it properly. Many countries are classifying all hospital waste as infectious Keeping in mind the high contagious nature of SARSCoV-2. The medical wastes are subjected to be incinerated under high temperature and after that the residual ash is used as land-filling [10].

Incineration and steam sterilization in $120^{\circ} \mathrm{C}$ for $90 \mathrm{mins}$ are the common methods for thermal disposal of hazardous medical waste. Recommendation of the incineration by the WHO for health-care waste is between 900 and $1200^{\circ} \mathrm{C}$ [43]. The countries like Germany, Spain, U.S.A have set their own priorities and guidelines for disposals of the solid wastes which includes single used plastics, health-care and hospital waste etc. keeping in mind the extensively increased production of those during the pandemic situation. For example, several states in the U.S. have also stopped recycling programs. The authorities have been concerned about the risk of spreading of COVID-19 in recycling centers and both incineration and land-filling have been given priority [42].

\section{CONCLUSION}

Based on the present study it it very clear that the COVID 19 pandemic situation has caused a positive impact on the environment. The atmosphere, hydrosphere and the biosphere have received a cleansing treatment which has been observed throughout the globe. The individual parameters of air and water quality has been improved during the lockdown period in all the big cities all over the world mainly due to drastic decrease of decarbonization and release of industrial and agricultural effluents. Also, the wildlife had been benefited by the expanded ecological niche due to restrictions of human interventions during the worldwide lockdown. On the other hand, the pandemic situation has given a huge challenge of waste disposal especially medical and single use plastic wastes in front of every cities and urban areas across the globe. And also, there is an unavoidable challenge of eradicating SARS-CoV-2 from the water and 
waste-water systems. In a nut shell the COVID-19 situation has been a boon and at the same time a bane keeping in mind all the environmental aspects across the planet earth. The sustainability of the improvement of air and water quality depends on the mass awareness about the rejuvenation achieved during the COVID-19 situation.

\section{REFERENCES}

[1] Guerrero-Latorre, L., Ballesteros, I., Villacrés-Granda, I., Granda, M. G., Freire-Paspuel, B., \& Ríos-Touma, B. (2020). SARS-CoV-2 in river water: Implications in low sanitation countries. The Science of the total environment, 743 , 140832. https://doi.org/10.1016/j.scitotenv.2020.140832

[2] Collivignarelli, M. C., Collivignarelli, C., Carnevale Miino, M., Abbà, A., Pedrazzani, R., \& Bertanza, G. (2020). SARS-CoV-2 in sewer systems and connected facilities. Process safety and environmental protection : transactions of the Institution of Chemical Engineers, Part B, 143, 196-203. https://doi.org/10.1016/j.psep.2020.06.049.

[3] Muhammad Farhan Bashir, Benjiang Ma, Bilal, Bushra Komal, Muhammad Adnan Bashir, Duojiao Tan, Madiha Bashir (2020). Correlation between climate indicators and COVID-19 pandemic in New York, USA. The Science of the total environment, 728, 138835.

[4] Shefali Arora, Kanchan Deoli Bhaukhandi, Pankaj Kumar Mishra (2020). Coronavirus lockdown helped the environment to bounce back. The Science of the total environment, 742, 140573.

[5] Saeida Saadat, Deepak Rawtani, Chaudhery Mustansar Hussain (2020). Environmental perspective of COVID-19. The Science of the Total Environment, $728,138870$.

[6] Saoul Manentia , Emiliano Morib , Viola Di Canioa , Silvia Mercurioa, Marco Piconec, Mario Caffid, Mattia Brambillae, Gentile Francesco Ficetolaa, Diego Rubolini, The good, the bad and the ugly of COVID-19 lockdown effects on wildlife conservation: Insights from the first European locked down country, Biological Conservation 249 (2020) 108728

[7] Mohammad Arif, Rajesh Kumar, Shagufta Parveen (2020). Reduction in Water Pollution in Yamuna River due to lockdown under COVID-19 Pandemic. ChemRxiv. Preprint. https://doi.org/10.26434/chemrxiv.12440525.v1

[8] Biswaranjan Paital, Kabita Das, Sarat Kumar Parida (2020). Inter nation social lockdown versus medical care against COVID-19, a mild environmental insight with special reference to India. Science of the Total Environment. $\quad 728$. 10.1016/j.scitotenv.2020.138914

[9] Sulaman Muhammad, Xingle Long, Muhammad Salman (2020). COVID-19 pandemic and environmental pollution: A blessing in disguise?. The Science of the total environment, 728, 138820.

[10] Ana L. Patrício Silva, Joana C. Prata, Tony R. Walker, Armando C. Duarte, Wei Ouyang, Damià Barcelò, Teresa
Rocha-Santos. Increased plastic pollution due to COVID19 pandemic: Challenges and recommendations. Chemical engineering journal (Lausanne, Switzerland: 1996) vol. 405 (2021): 126683.

[11] Manuel A. Zambrano-Monserrate, María Alejandra Ruano, Luis Sanchez-Alcalde (2020). Indirect effects of COVID-19 on the environment. The Science of the Total Environment 728, 138813.

[12] Preet Lal, Amit Kumar, Shubham Kumar, Sheetal Kumari, Purabi Saikia, Arun Dayanandan, Dibyendu Adhikari, M.L. Khan (2020). The dark cloud with a silver lining: Assessing the impact of the SARS COVID-19 pandemic on the global environment. The Science of the total environment, 732, 139297.

[13] Snehal Lokhandwala, Pratibha Gautam (2020). Indirect impact of COVID-19 on environment: A brief study in Indian context. Environmental Research, 188, 109807.

[14] CPCB, 2020. Report on Impact of lockdown on River Yamuna Water Quality. https://cpcb.nic.in/index.php.

[15] Amanda E. Bates, Richard B. Primack, Paula Moraga and Carlos M. Duarte (2020). COVID-19 Pandemic and Associated Lockdown as a "Global Human Confinement Experiment" to Investigate Biodiversity Conservation. Biological conservation, 248, 108665.

[16] Bakar, N.A., Rosbi. S., 2020. Effect of Coronavirus disease (COVID -19) to tourism industry. Int. J. Adv. Eng. Res. Sci. 7, doi:10.22161/ijaers.74.23

[17] Gray, R.S., 2020. Agriculture, transportation, and the COVID - 19 crisis. Can. J. Agri. Econ. 2020; 1 -5. doi:10.1111/cjag.12235

[18] Pepe, E., Bajardi, P., Gauvin, L., Privitera, F., Lake, B., Cattuto, C., Tizzoni. M., 2020. COVID -19 outbreak response: a first assessment of mobility changes in Italy following national lockdown. medRxiv. 2020.03.22.20039933. doi:10.1101/2020.03.22.20039933

[19] Rutz, C., Loretto, M -C., Bates, A.E., Davidson, S.C., Duarte, C.M., Jetz, W., Johnson, M., Kato, A., Kays, R., Mueller, T., Primack, R.B., Ropert -Coudert, Y., Tucker, M., Wikelski, M., Cagnacci, F., 2020. COVID -19 lockdown allows researchers to quantify the effects of human activity on wildlife. Nat. Ecol. Evo. (accepted)

[20] Paital B. (2020). Nurture to nature via COVID-19, a selfregenerating environmental strategy of environment in global context. The Science of the total environment, 729, 139088. https://doi.org/10.1016/j.scitotenv.2020.139088.

[21] Loring, K., 2020. In San Francisco, coyotes are your wildest neighbors. https://www.kalw.org/ post/sanfrancisco-coyotes-are-your-wildest-neighbors (retrieved on 23.042020).

[22] Child, D., 2020. The positive impacts on the environment since the coronavirus lockdown began. https://www.standard.co.uk/news/world/positive-impactenvironment-coronavirus-lockdown-a4404751.html (retrieved on 23.042020).

[23] Rupani P. F., Nilashi M, Abumalloh R. A., Asadi S., Samad S., Wang S. Coronavirus pandemic (COVID-19) and its natural environmental impacts. International 
Journal of Environmental Science and Technology (2020) 17:4655-4666.

[24] Pratibha Sharma, Dr. Manpreet Kaur and Gaurav Narwal. Other side of the COVID-19 Pandemic: A Review. The Pharma Innovation Journal 2020; 9(5): 366-369.

[25] Yunus, A. P., Masago, Y., \& Hijioka, Y. (2020). COVID19 and surface water quality: Improved lake water quality during the lockdown. The Science of the total environment, $731, \quad 139012$. https://doi.org/10.1016/j.scitotenv.2020.139012

[26] Pathak, S.S., Mishra, P., 2020. A review of the Ganga river water pollution along major urban centres in the state of Uttar Pradesh, India. Int. Res. J. Eng. Technol. 7 (3), 1202-1210.

[27] Bhowmick, G.D., Dhar, D., Nath, D. et al. Coronavirus disease 2019 (COVID-19) outbreak: some serious consequences with urban and rural water cycle. npj Clean Water 3, 32 (2020). https://doi.org/10.1038/s41545-020$0079-1$

[28] Corburn, J., Vlahov, D., Mberu, B., Riley, L., Caiaffa, W. T., Rashid, S. F., Ko, A., Patel, S., Jukur, S., MartínezHerrera, E., Jayasinghe, S., Agarwal, S., Nguendo-Yongsi, B., Weru, J., Ouma, S., Edmundo, K., Oni, T., \& Ayad, H. (2020). Slum Health: Arresting COVID-19 and Improving Well-Being in Urban Informal Settlements. Journal of urban health : bulletin of the New York Academy of Medicine, 97(3), 348-357. https://doi.org/10.1007/s11524-020-00438-6

[29] Daughton C. G. (2020). Wastewater surveillance for population-wide Covid-19: The present and future. The Science of the total environment, 736, 139631. https://doi.org/10.1016/j.scitotenv.2020.139631

[30] Hart, O. E., \& Halden, R. U. (2020). Computational analysis of SARS-CoV-2/COVID-19 surveillance by wastewater-based epidemiology locally and globally: Feasibility, economy, opportunities and challenges. The Science of the total environment, 730, 138875. https://doi.org/10.1016/j.scitotenv.2020.138875.

[31] Kumar, M., Patel, A. K., Shah, A. V., Raval, J., Rajpara, N., Joshi, M., \& Joshi, C. G. (2020). First proof of the capability of wastewater surveillance for COVID-19 in India through detection of genetic material of SARS-CoV2. The Science of the total environment, 746, 141326. https://doi.org/10.1016/j.scitotenv.2020.141326.

[32] La Rosa, G., Iaconelli, M., Mancini, P., Bonanno Ferraro, G., Veneri, C., Bonadonna, L., Lucentini, L., \& Suffredini, E. (2020). First detection of SARS-CoV-2 in untreated wastewaters in Italy. The Science of the total environment, 736 , 139652. https://doi.org/10.1016/j.scitotenv.2020.139652

[33] Randazzo, W., Truchado, P., Cuevas-Ferrando, E., Simón, P., Allende, A., \& Sánchez, G. (2020). SARS-CoV-2
RNA in wastewater anticipated COVID-19 occurrence in a low prevalence area. Water research, 181, 115942. https://doi.org/10.1016/j.watres.2020.115942

[34] Langone M, Petta L, Cellamare CM, et al. SARS-CoV-2 in water services: Presence and impacts. Environmental Pollution (Barking, Essex: 1987). 2020 Oct;268(Pt A):115806. DOI: 10.1016/j.envpol.2020.115806. 268 (2021)115806.

[35] Wigginton, K.R., Ye, Y., Ellenberg, R.M., 2015. Emerging Investigators Series: the source and fate of pandemic viruses in the urban water cycle. Environ. Sci. Water Res. Technol. 1, 725e924. https://doi.org/10.1039/C5EW00125K.

[36] Liu, Y., Li, T., Deng, Y., Liu, S., Zhang, D., Li, H., Wang, X., Ji, L., Han, J., Bei, Z., Zhou, Y., Li, L., Li, J., 2020 b. Stability of SARS-CoV-2 on environmental surfaces and in human excreta. Prepr, 20094805

[37] Rimoldi, S.G., Stefani, F., Gigantiello, A., Polesello, S., Comandatore, F., Mileto, D., Maresca, M., Longobardi, C., Mancon, A., Romeri, F., Pagani, C., Moja, L., Gismondo, M.R., Salerno, F., 2020. Presence and vitality of SARS-CoV-2 virus in wastewaters and rivers. Prepr, 20086009.

[38] Hai Nguyen Tran, Giang Truong Le, Dong Thanh Nguyen, Ruey-Shin Juang, Jörg Rinklebe, Amit Bhatnagar, Eder C. Lima, Hafiz M.N. Iqbal, Ajit K. Sarmah, Huan-Ping Chao (2020). SARS-CoV-2 coronavirus in water and wastewater: A critical review about presence and concern. Environmental Research, 110265.

[39] Wang, W., Xu, Y., Gao, R., Lu, R., Han, K., Wu, G. and Tan, W. 2020. Detection of SARS-CoV-2 in 799 different types of clinical specimens. JAMA 323(18), 1843-1844.

[40] Wang, P., Kaiyu, C., Zhu, S., Wang, P., Zhang, H., 2020. Severe air pollution events not avoided by reduced anthropogenic activities during COVID -19 outbreak. Resour. Conserv. Recy.158, 104814.

[41] Hale R. C. and Song B. (2020). Single-Use Plastics and COVID-19: Scientific Evidence and Environmental Regulations. Environmental science and technology, 54(12), 7034-7036.

[42] Jiří Jaromír Klemeŝ, Yee Van Fan, Raymond R. Tan, Peng Jiang (2020). Minimising the present and future plastic waste, energy and environmental footprints related to COVID-19. Renewable and Sustainable Energy Reviews, 127,109883

[43]WHO - World Health Organisation, Treatment and disposal technologies for healthcare waste accessed 07.04.2020. 